\title{
Key Challenges and Barriers Facing Small \& Medium Enterprises (SMEs) in Bangladesh
}

\author{
Dr. Anupam Mazumdar ${ }^{1}$, Husam Alharahsheh ${ }^{2^{*}}$ \\ ${ }^{1}$ Lecturer at University of Wales Trinity Saint David, College St, Lampeter SA48 7ED, United Kingdom \\ 2Lecturer in Business Management at University of Wales Trinity Saint David - London and Senior visiting lecturer across several UK \\ and international Higher Education Institutions, College St, Lampeter SA48 7ED, United Kingdom
}

*Corresponding Author
Husam Helmi Alharahsheh

Article History

Received: 16.10 .2019

Accepted: 24.10.2019

Published: 05.11.2019

\begin{abstract}
In Bangladesh, SMEs play a dominant role in the national economy as well as contributing to gross domestic product $[2,3]$. The government has already taken some initiatives to support SMEs such as establishing SME foundation, dealing with SME sectors' problems and facilitating and promoting SME development. However, there are many factors that SME foundations are unable to perform due to inadequate resources and policies. Therefore, this brief paper is aiming to highlight these factors at the present time facing SMEs in the country. The paper is mainly dependent on a secondary research through screening key publications in the literature to determine those factors. The paper has included a general overview of these factors including insufficiency of resources and information, employee turnover and low levels of productivity, poor physical infrastructure and utility support, interest rates and bank loans, availability of appropriate technology, skilled manpower, lack of government support, and external changes. This brief paper opens key considerations for researchers in the field to further explore these factors and to enhance further understanding, and provide key solutions to overcome these challenges to be considered by SMEs, entrepreneurs, and policy developers in the country.

Keywords: SMEs, Challenges and Barriers, Bangladesh, Policy.
\end{abstract}

\section{INTRODUCTION}

In Bangladesh, SMEs play a dominant role in the national economy as well as contributing to gross domestic product [2, 3]. Apart from some nourishment industries, medicine companies, adhesive factories and telecoms businesses, the remainder of the business entities are SMEs in Bangladesh and they are almost 6.0 million [2]. These SMEs are producing about 50\% of the country's business output every year by generating the largest amount of employment and by contributing import substitution in many ways, creating low price class products, creating import subsidiary products and by saving oversees currencies [2]. But the question is what are the initiatives government has taken to boost SMEs to get their support to make the country a middle-income country?.

According to [2], the government has already taken some initiatives to support SMEs such as establishing SME foundation, dealing with SME sectors' problems and facilitating and promoting SME development. Abdin, M. J et al., [2] claimed in his article "Bangladesh's SMEs are facing so many challenges" that the government's key achievement is building a SME Foundation for encouraging SMEs and to direct financial providers to simplify SME loans for very poor SMEs. But still there are many things that SME Foundation are unable to perform due to inadequate resources and policies [2]. Below is addressing the various barriers and challenges that SME subdivisions are facing at the moment of time in Bangladesh.

\section{Insufficiency of Resource and Information}

There is huge insufficiency of raw materials in Bangladesh, which obstructs the ability of SME subdivisions to be export friendly and restricts SMEs' capability of reaching further stages in global business expansion [1]. In Bangladesh, SMEs have much

Copyright @ 2019: This is an open-access article distributed under the terms of the Creative Commons Attribution license which permits unrestricted use, distribution, and reproduction in any medium for non commercial use (NonCommercial, or CC-BY-NC) provided the original author and source are credited. 
less capacity to use information technology [6]. Only $1 \%$ - $2 \%$ of SMEs are using accounting software packages and about $15 \%$ of SMEs are using computers in their business. In addition, in terms of SME use of the Internet, this proportion is just below 10\% [1].

\section{High Employee Turnover and Low Productivity}

It seems that because of inadequate development in SMEs (especially in IT-related adoption), a large number of skilled employees are leaving SMEs because they believe that SMEs are very good as knowledge originators but not good enough for knowledge retention [1-5]. In Bangladesh, SME subdivisions are employing nearly $82 \%$ of workforce but, unfortunately, producing only $50 \%$ of business output, which shows that the workforce in SME subdivisions are really less productive [2].

\section{Poor Physical Infrastructure and Utility Support:}

There is a tendency in Bangladeshi peoples' minds that industrialization should be urbanized and capital based and this is owing to an inadequate supply of infrastructure amenities [2]. At present a basic utility like electricity supply has improved but it is still not easy to get continuous supply in rural areas [2]. Other utilities such as gas, water, roads and highways are obstructing the development of SMEs in respect of making supply chains efficient or transport of goods downstream - especially from rural areas. Hostile topographical circumstances increase transport costs [1]. At the moment, poor infrastructure and disrupted utility supply is one of the main challenges for Bangladeshi SMEs [2].

\section{High Bank Interest Rates and Absence of Security Free Bank Loans}

At present for a Bangladeshi SMEs, bank loan interest is $13 \%$ set by the central bank of Bangladesh, which is relatively too high according to [2]. For SME owners to retain a profit margin with $13 \%$ high interest on loans, hiring employees, paying wages, rents and utilities, they need to sell their products at more than $50 \%$ more than their production cost, which is just impossible. To get competitive advantage SMEs need to produce high quality products but double-digit bank interest rates makes achieving those advantages unthinkable [2]. They (SME owner/manager) need finance to bring their entrepreneurial dreams into reality but they do not have a guarantor to get a bank loan [2]. Bangladesh Bank, the central bank of Bangladesh, takes the view that SMEs are at the extreme risk of borrowers since they do not have capabilities to meet the bank's guarantee requirements [2, 3]. According to [1], only $15 \%-20 \%$ of SME proprietors have fixed assets and banks are issuing loans based on those assets. Therefore, about $80 \%$ of the SMEs are not getting bank loans, as they do not have fixed assets to produce as guarantor. Lack of access to bank loans is a serious inhibitor to SME development - certainly to investment in ICT technologies.

\section{Availability of Advanced Technology:}

One of the key barriers to the expansion of Bangladeshi SMEs is inadequate technology being used. Many SMEs cannot develop because the difficulty in adopting technology [1]. Abdin, M. J et al., found out that majority of the SMEs in Bangladesh are using local machinery and in house technology (for limited use only) to produce products but the reality is that those products are not sufficiently productive to meet market requirements. Moreover, there are a lot of Indian and Chinese low cost products available in the Bangladeshi local markets. Therefore, Bangladeshi SME owners or entrepreneurs are losing income owing to not having sufficient technical knowledge [2, 3].

\section{Lack of Sector Specific Skilled Manpower and Absence of an SME Entrepreneurship Program}

The expansion of Information and Communication Technology is improving but, in Bangladesh, there are too few high standard ICT academies available with the full equipment of advanced technologies for our fast developing industrial subdivisions. These would be needed to provide training to people to hire in that area [1-3]. Quite surprisingly in Bangladesh there is not a neither single training agency nor academic institute available for SME entrepreneurs to undertake learning and training required, which shows that SMEs are not getting skilled manpower to perform tasks to deliver and execute their business plan [2].

\section{Lack of Government Support}

To start a business whether it would be small or medium size, business owners need a series of clearances, registrations and licences from different authorities and even from a different ministry of the Bangladeshi government. Completing those formalities is difficult for a normal person [2]. Moreover, they need to pass bribes to almost every desk with their file, which is highly demotivating for them [2]. According to [2], Bangladesh government should have taken different approach for the SME owner/manager to make procedures easier to get all the clearance done from the same authorities under the same roof to save times and unnecessary hassle in order to make process faster to start a business and to make SME owner/manager satisfied.

\section{External Shocks}

Compared to large businesses, SMEs are relatively weak in terms of decision-making, structure of management and business planning, which exacerbates the problem of SMEs being able to cope with many business jeopardies and uncertainties [4]. In addition, SME subdivisions are vulnerable to the financial and economic circumstances [7]. The impact of external shocks is that a majority of SMEs are facing a wider variety of uncertainties and jeopardies, which are rooted in the combination of internal and external environment of the businesses. Similarly, when it comes to technology adoption, owner/manager or SME subdivisions necessarily do not want to put their business in that situation where risks and uncertainties are associated. 


\section{Conclusions}

The barriers above mentioned are in general for Bangladeshi SMEs. The paper has included a general overview of these factors including insufficiency of resources and information, employee turnover and low levels of productivity, poor physical infrastructure and utility support, interest rates and bank loans, availability of appropriate technology, skilled manpower, lack of government support, and external changes. This brief paper opens key considerations for researchers in the field to further explore these factors and to enhance further understanding, and provide key solutions to overcome these challenges to be considered by SMEs, entrepreneurs, and policy developers in the country.

\section{ReferenCes}

1. Ahmed, K., \& Chowdhury, T. A. (2009). Performance Evaluation of SMEs of Bangladesh. International Journal of Business and Management, 4(7).

2. Abdin, M. J. (2010). Bangladesh's SMEs facing so many Challenges. [Adapted from: <https://joynal.wordpress.com/2010/08/01/bangladeshs-smes-facing-so-manychallenges/>Accessed on 07/01/2016].

3. Abdin, M. J. (2014). Vision-2021: The role of small and medium enterprises [Retrieved from: <https://joynal.wordpress.com/tag/smes-in-bangladesh/> Accessed on 04/01/2016].

4. Fatai, A. (2010) Small and Medium Scale Enterprise in Nigeria: The Problems and Prospects. The Collegiate Journal of Economics, 1, 16 -18.

5. Levy, M., Loebbecke, C. \& Powell, P. (2003). SMEs, Cooperation and Knowledge Sharing: the Role of Information System European Journal of Information System, Vol. 12.

6. Miah, M. A. (2006). Key Success Factors for National SME Development Program; Lessons for OIC Member Countries from Bangladesh Experience, SME Foundation, Dhaka, Bangladesh.

7. Suh, J. D. (2010). Risks and Opportunities facing SMEs in the post-crisis Era. Poster presented at the APEC SMEs Training Workshop, Taipei, Korea May 24th - 28th, May 